\title{
Four New Triterpene Glycosides from Nigella damascena
}

\author{
Hitoshi Yoshimitsu, ${ }^{*, a}$ Makiko Nishida, ${ }^{b}$ Masafumi OKawa, ${ }^{c}$ and Toshihiro Nohara ${ }^{d}$ \\ ${ }^{a}$ Faculty of Pharmaceutical Sciences, Sojo University; 4-22-1 Ikeda, Kumamoto 862-0082, Japan: ${ }^{b}$ Faculty of \\ Engineering, Kyushu Kyoritsu University; 1-8 Jiyugaoka, Yahata-nishi-ku, Kitakyushu 807-8585, Japan: ${ }^{c}$ Faculty of \\ Pharmaceutical Sciences, Fukuoka University; 8-19-1 Nanakuma, Jonan-ku, Fukuoka 814-0180, Japan: and ${ }^{d}$ Faculty of \\ Medical and Pharmaceutical Sciences, Kumamoto University; 5-1 Oe-honmachi, Kumamoto 862-0973, Japan. \\ Received November 15, 2006; accepted December 22, 2006; published online December 26, 2006
}

Four new triterpene glycosides, named nigellosides A, B, C, and D, were from the air-dried aerial parts of Nigella damascena $\mathrm{L}$. (Ranunculaceae), and the structures were elucidated on the basis of spectroscopic data including 2D NMR spectra and chemical evidence. Their chemical structures have been characterized as 3-O- $\alpha$-Lrhamnopyranosyl-(1 $\rightarrow 2)$ - $\alpha$-L-arabinopyranosyl gypsogenin 28 - $\beta$-D-glucopyranosyl-( $1 \rightarrow 6)$ - $\beta$-D-glucopyranosyl ester, 3-O- $\beta$-D-glucopyranosyl-( $1 \rightarrow 3)$ - $\alpha$-L-rhamnopyranosyl-(1 $\rightarrow 2)$ - $\alpha$-L-arabinopyranosyl gypsogenin $28-\beta$-D-glucopyranosyl-(1 $\rightarrow 6)$ - $\beta$-D-glucopyranosyl ester, 3- $O$ - $\alpha$-L-rhamnopyranosyl-(1 $\rightarrow 2)$ - $\beta$-D-xylopyranosyl hederagenin 28 - $\beta$-D-glucopyranosyl-( $\rightarrow 6)$ - $\beta$-D-glucopyranosyl ester, and 3 - $O$ - $\beta$-D-glucopyranosyl- $(1 \rightarrow 3)$ - $\alpha$-L-rhamnopyranosyl-( $1 \rightarrow 2)$ - $\beta$-D-xylopyranosyl hederagenin $28-\beta$-D-glucopyranosyl- $(1 \rightarrow 6)$ - $\beta$-D-glucopyranosyl ester.

Key words Nigella damascena; nigelloside; oleanene glycoside; Ranunculaceae

The genus Nigella with some 20 species belongs to Ranunculaceae. These are distributed from the southern area of Europa to the northern Africa, the southwestern Asia, and the Central Asia. Nigella damascena L. (Japanese name, kurotanesou) is cultivated as a garden plant. From its seeds, alkaloid, ${ }^{1)}$ sesquiterpenes, ${ }^{2)}$ and phenolic compounds ${ }^{3)}$ were isolated. A survey of the literature showed no chemical work being done on the aerial parts of $N$. damascena. As part of our continuing investigation on the chemical constituents in the Ranunculaceous plants, ${ }^{4-6)}$ this paper deals with structural elucidation of four new triterpene glycosides, named nigellosides A (1), B (2), C (3), and D (4).

\section{Results and Discussion}

The methanolic extract of the air-dried aerial parts of $N$. damascena was partitioned into a chloroform-water solvent system. The water-soluble portion was separated by MCI gel CHP20P, octadecyl silica gel (ODS), and silica gel column chromatographies, and finally HPLC to give nigellosides A (1), B (2), C (3), and D (4) together with eight triterpene glycosides, $3-O-\beta$-D-glucopyranosyl-( $1 \rightarrow 3)-\alpha$-L-rhamnopyranosyl-( $1 \rightarrow 2)-\alpha$-L-arabinopyranosyl hederagenin $28-\beta$-D-glucopyranosyl-( $(1 \rightarrow 6)-\beta$-D-glucopyranosyl ester $(\mathbf{5}){ }^{7)}$ dipsacoside B (6), ${ }^{8)} 3-O-\beta$-D-glucopyranosyl-( $\left.1 \rightarrow 3\right)$ - $\alpha$-L-rhamnopyranosyl-( $1 \rightarrow 2)-\alpha$-L-arabinopyranosyl hederagenin $28-\beta$-Dglucopyranosyl ester (7), ${ }^{9)} 3-O-\beta$-D-glucopyranosyl-( $(1 \rightarrow 3)$ $\alpha$-L-rhamnopyranosyl-( $(1 \rightarrow 2)-\alpha$-L-arabinopyranosyl oleanolic acid 28- $\beta$-D-glucopyranosyl-( $1 \rightarrow 6)-\beta$-D-glucopyranosyl ester $(\mathbf{8}),{ }^{10)} \quad 3-O-\beta$-D-glucopyranosyl-( $(1 \rightarrow 3)-\alpha$-L-rhamnopyranosyl-( $(1 \rightarrow 2)-\beta$-D-xylopyranosyl oleanolic acid $28-\beta$-D-glu-
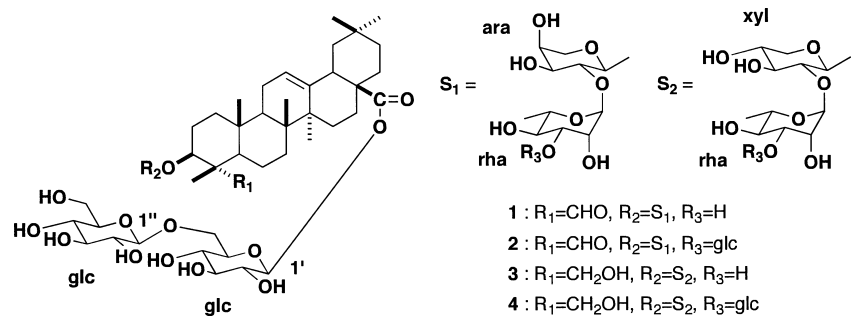

copyranosyl-(1 $\rightarrow 6)$ - $\beta$-D-glucopyranosyl ester (9), ${ }^{11)} 3-O-\alpha$ L-rhamnopyranosyl- $(1 \rightarrow 2)$ - $\alpha$-L-arabinopyranosyl oleanolic acid 28 - $\beta$-D-glucopyranosyl-( $1 \rightarrow 6)$ - $\beta$-D-glucopyranosyl ester (10) ${ }^{12)}$ anhuienside $\mathrm{C}(\mathbf{1 1}),{ }^{13)}$ and hederagenin $3-O-\alpha$-Lrhamnopyranosyl-( $(1 \rightarrow 2)-\alpha$-L-arabinopyranoside (12). ${ }^{14)}$

The molecular formula of nigelloside A (1) was determined as $\mathrm{C}_{53} \mathrm{H}_{84} \mathrm{O}_{22}$ by high-resolution (HR)-ESI-MS showing a $\left[\mathrm{C}_{53} \mathrm{H}_{84} \mathrm{O}_{22} \mathrm{Na}\right]^{+}$ion at $\mathrm{m} / z$ 1095.5361. The ${ }^{1} \mathrm{H}-\mathrm{NMR}$ spectrum revealed signals due to six quaternary methyls at $\delta$ $0.87,0.88,0.89,1.05,1.21$, and 1.39 , an olefinic proton at $\delta$ $5.39(1 \mathrm{H}, \mathrm{brs})$, an aldehyde proton at $\delta 9.67(\mathrm{~s})$, and four anomeric protons at $\delta 4.72(\mathrm{~d}, J=5.8 \mathrm{~Hz}), 5.01(\mathrm{~d}, J=$ $7.6 \mathrm{~Hz}), 6.06(\mathrm{brs})$, and $6.22(\mathrm{~d}, J=7.9 \mathrm{~Hz})$. The ${ }^{13} \mathrm{C}-\mathrm{NMR}$ spectrum displayed signals due to six quaternary carbon at $\delta$ $30.8,36.1,40.1,42.2,47.0$, and 55.4, an oxygen-bearing methine carbon at $\delta 80.2$, a set of olefinic carbon at $\delta 122.6$ and 144.2 , an ester carbonyl carbon at $\delta 176.5$, an aldehyde carbon at $\delta 207.6$, and four anomeric carbons at $\delta 95.7,101.4$, 102.0, and 105.3. A detailed analysis of these spectral data indicated that 1 was the 3,28-bisdesmoside of gypsogenin, ${ }^{15}$ ) having four monosaccharide units. The configuration of the hydroxyl group at C-3, bearing a saccharide moiety, was determined to be $\beta$ from the coupling constants of the proton (dd, $J=4.6,11.5 \mathrm{~Hz}, \mathrm{H}-3$ ). Hydrolysis of 1 afforded L-arabinose, D-glucose, and L-rhamnose, the structure of which was confirmed by the ${ }^{1} \mathrm{H}-\mathrm{NMR}$ coupling pattern and optical rotation using chiral detection in the HPLC analysis, together with gypsogenin. The NMR data could be assigned with the aid of ${ }^{1} \mathrm{H}-{ }^{1} \mathrm{H}$ correlation spectroscopy (COSY), ${ }^{1} \mathrm{H}$-detected heteronuclear multiple quantum coherence (HMQC) and heteronuclear multiple bond connection (HMBC) experiments. The anomeric centers of the arabinose and glucose moieties were determined to be $\alpha$ - and $\beta$-configurations, respectively, from each ${ }^{3} J_{\mathrm{H} 1-\mathrm{H} 2}$ value. The anomeric configuration of rhamnose could not be deduced from the ${ }^{3} J_{\mathrm{H} 1-\mathrm{H} 2}$ value. However, the ${ }^{13} \mathrm{C}$ shifts of the rhamnose were superimposable on those of methyl $\alpha$-L-rhamnopyranoside. The presence of a 2substituted $\alpha$-L-arabinopyranosyl $\left({ }^{4} \mathrm{C}_{1}\right)$ unit, a 2-substituted $\beta$-D-glucopyranosyl $\left({ }^{4} \mathrm{C}_{1}\right)$ unit, a terminal $\beta$-D-glucopyranosyl $\left({ }^{4} \mathrm{C}_{1}\right)$ unit, and a terminal $\alpha$-L-rhamnopyranosyl $\left({ }^{1} \mathrm{C}_{4}\right)$ 
Table $1 .{ }^{13} \mathrm{C}-\mathrm{NMR}$ Data for $\mathbf{1}-\mathbf{4}$ (in Pyridine- $d_{5}, 125 \mathrm{MHz}, \delta \mathrm{ppm}$ )

\begin{tabular}{|c|c|c|c|c|c|c|c|c|c|}
\hline & 1 & 2 & 3 & 4 & & 1 & 2 & 3 & 4 \\
\hline C- 1 & 38.3 & 38.4 & 39.2 & 39.1 & $3-O-$ & ara & ara & xyl & xyl \\
\hline 2 & 25.2 & 25.5 & 26.5 & 26.6 & C-1 & 102.0 & 102.9 & 105.3 & 105.5 \\
\hline 3 & 80.2 & 80.6 & 80.9 & 81.2 & 2 & 75.3 & 74.8 & 77.8 & 76.9 \\
\hline 4 & 55.4 & 55.6 & 43.5 & 43.6 & 3 & 73.8 & 74.6 & 79.7 & 79.6 \\
\hline 5 & 48.4 & 48.4 & 47.8 & 47.6 & 4 & 68.7 & 69.4 & 71.5 & 71.5 \\
\hline 6 & 20.6 & 20.6 & 18.2 & 18.1 & 5 & 65.0 & 66.1 & 67.0 & 67.0 \\
\hline 7 & 32.5 & 32.5 & 32.9 & 32.8 & & rha & rha & rha & rha \\
\hline 8 & 40.1 & 40.2 & 39.9 & 39.9 & C-1 & 101.4 & 101.3 & 101.8 & 101.4 \\
\hline 9 & 47.9 & 47.9 & 48.2 & 48.2 & 2 & 72.4 & 71.9 & 72.3 & 71.7 \\
\hline 10 & 36.1 & 36.1 & 36.9 & 36.9 & 3 & 72.5 & 83.3 & 72.6 & 83.1 \\
\hline 11 & 23.7 & 23.7 & 23.9 & 23.8 & 4 & 74.2 & 73.1 & 74.2 & 73.0 \\
\hline 12 & 122.6 & 122.6 & 122.9 & 122.9 & 5 & 69.7 & 69.6 & 69.7 & 69.8 \\
\hline 13 & 144.2 & 144.2 & 144.1 & 144.1 & 6 & 18.6 & 18.5 & 18.7 & 18.6 \\
\hline 14 & 42.2 & 42.2 & 42.2 & 42.1 & & & glc & & glc \\
\hline 15 & 28.2 & 28.2 & 28.3 & 28.3 & $C-1^{\prime \prime \prime}$ & & 106.8 & & 106.9 \\
\hline 16 & 23.3 & 23.3 & 23.4 & 23.4 & $2^{\prime \prime \prime}$ & & 76.1 & & 75.9 \\
\hline 17 & 47.0 & 47.0 & 47.1 & 47.0 & $3^{\prime \prime \prime}$ & & 78.4 & & 78.4 \\
\hline 18 & 41.7 & 41.7 & 41.7 & 41.7 & $4^{\prime \prime \prime}$ & & 71.5 & & 71.5 \\
\hline 19 & 46.2 & 46.2 & 46.2 & 46.2 & $5^{\prime \prime \prime}$ & & 78.8 & & 78.7 \\
\hline 20 & 30.8 & 30.8 & 30.7 & 30.7 & $6^{\prime \prime \prime}$ & & 62.5 & & 62.5 \\
\hline 21 & 34.0 & 34.0 & 34.0 & 34.0 & $28-O-$ & glc & glc & glc & glc \\
\hline 22 & 32.4 & 32.4 & 32.6 & 32.6 & $\mathrm{C}-1^{\prime}$ & 95.7 & 95.7 & 95.7 & 95.7 \\
\hline 23 & 207.6 & 207.6 & 63.8 & 63.9 & $2^{\prime}$ & 73.9 & 73.9 & 73.9 & 73.9 \\
\hline 24 & 10.6 & 10.8 & 14.1 & 14.2 & $3^{\prime}$ & 78.7 & 78.6 & 78.7 & 78.6 \\
\hline 25 & 15.7 & 15.7 & 16.2 & 16.2 & $4^{\prime}$ & 70.9 & 71.0 & 71.0 & 71.0 \\
\hline 26 & 17.5 & 17.5 & 17.6 & 17.5 & $5^{\prime}$ & 78.0 & 78.0 & 78.0 & 78.0 \\
\hline 27 & 26.0 & 26.1 & 26.1 & 26.1 & $6^{\prime}$ & 69.4 & 69.5 & 69.4 & 69.4 \\
\hline 28 & 176.5 & 176.5 & 176.5 & 176.5 & & glc & glc & glc & glc \\
\hline 29 & 33.1 & 33.1 & 33.1 & 33.1 & $\mathrm{C}-1^{\prime \prime}$ & 105.3 & 105.3 & 105.3 & 105.3 \\
\hline \multirow[t]{5}{*}{30} & 23.7 & 23.7 & 23.7 & 23.7 & $2^{\prime \prime}$ & 75.2 & 75.2 & 75.2 & 75.2 \\
\hline & & & & & $3^{\prime \prime}$ & 78.4 & 78.5 & 78.5 & 78.4 \\
\hline & & & & & $4^{\prime \prime}$ & 71.5 & 71.6 & 71.6 & 71.5 \\
\hline & & & & & $5^{\prime \prime}$ & 78.4 & 78.4 & 78.4 & 78.5 \\
\hline & & & & & $6^{\prime \prime}$ & 62.7 & 62.7 & 62.3 & 62.6 \\
\hline
\end{tabular}

unit was shown by comparison of the ${ }^{13} \mathrm{C}$ shifts for each monosaccharide. In the HMBC experiments, long-range correlations were observed between the anomeric proton $(\delta$ 4.72) of 2-substituted arabinosyl moiety and the C-3 $(\delta 80.2)$ of gypsogenin, the anomeric proton $(\delta 5.01)$ of terminal glucosyl moiety and the C-6' $(\delta 69.4)$ of 6-substituted glucosyl moiety, the anomeric proton $(\delta 6.06)$ of terminal rhamnosyl moiety and the C-2 $(\delta 75.3)$ of 2-substituted arabinosyl moiety, and the anomeric proton $(\delta 6.22)$ of 6 -substituted glucosyl moiety and the C-28 ( $\delta$ 176.5) of gypsogenin. From the above evidence, the structure of 1 was concluded to be 3-O$\alpha$-L-rhamnopyranosyl-( $1 \rightarrow 2)$ - $\alpha$-L-arabinopyranosyl gypsogenin 28 - $\beta$-D-glucopyranosyl- $(1 \rightarrow 6)-\beta$-D-glucopyranosyl ester.

The HR-ESI-MS of nigelloside B (2) showed a peak at $\mathrm{m} / \mathrm{z} 1257.5864$ corresponding to the molecular formula $\left[\mathrm{C}_{59} \mathrm{H}_{94} \mathrm{O}_{27} \mathrm{Na}\right]^{+}$(Calcd for 1257.5880). The ${ }^{1} \mathrm{H}-\mathrm{NMR}$ data were similar to those of $\mathbf{1}$ except for the new additional anomeric proton at $\delta 5.64(\mathrm{~d}, J=8.1 \mathrm{~Hz})$. In the ${ }^{13} \mathrm{C}-\mathrm{NMR}$ spectrum of 2 , signals due to the aglycon moiety and the saccharide moiety, attached to the carboxyl group at C-28, were in good agreement with those of $\mathbf{1}$, although the signals due to the saccharide moiety, attached to the hydroxyl group at C-3, were not identical. Hydrolysis of $\mathbf{2}$ afforded gypsogenin, L-arabinose, D-glucose, and L-rhamnose. Meanwhile, the molecular formula of 2 was higher by $\mathrm{C}_{6} \mathrm{H}_{10} \mathrm{O}_{5}$ (hexose unit) than that of $\mathbf{1}$. The above data indicated that an additional glucosyl unit was linked to the saccharide moiety attached to the hydroxyl group at $\mathrm{C}-3$. In the $\mathrm{HMBC}$ experiment, the anomeric proton signals at $\delta 4.65(\mathrm{~d}, J=6.3 \mathrm{~Hz}$, ara $\mathrm{H}-1)$, 6.17 (brs, rha H-1), and 5.64 (glc H-1"') showed long-range correlations with the carbon signals at $\delta 80.6$ (C-3), 74.8 (ara $\mathrm{C}-2$ ), and 83.3 (rha C-3), respectively. Therefore, the structure of 2 was formulated as 3-O- $\beta$-D-glucopyranosyl- $(1 \rightarrow 3)$ $\alpha$-L-rhamnopyranosyl-( $1 \rightarrow 2)-\alpha$-L-arabinopyranosyl gypsogenin 28 - $\beta$-D-glucopyranosyl-( $1 \rightarrow 6)$ - $\beta$-D-glucopyranosyl ester.

Nigelloside C (3) showed a clustered molecular ion at $\mathrm{m} / \mathrm{z}$ $1097.5492\left[\mathrm{C}_{53} \mathrm{H}_{86} \mathrm{O}_{22} \mathrm{Na}\right]^{+}$in the HR-ESI-MS. The ${ }^{1} \mathrm{H}-$ NMR spectrum revealed signals due to six quaternary methyls at $\delta 0.84,0.85,0.97,1.11,1.12$ and 1.17 , an olefinic proton at $\delta 5.39(1 \mathrm{H}, \mathrm{dd}, J=2.9,3.5 \mathrm{~Hz})$, and four anomeric protons at $\delta 5.01(\mathrm{~d}, J=8.0 \mathrm{~Hz}), 5.04(\mathrm{~d}, J=7.5 \mathrm{~Hz}), 6.23(\mathrm{~d}$, $J=8.1 \mathrm{~Hz})$, and $6.49(\mathrm{~d}, J=1.2 \mathrm{~Hz})$. The ${ }^{13} \mathrm{C}$-NMR spectrum displayed signals due to six quaternary carbon at $\delta 30.7$, $36.9,39.9,42.2,43.5$, and 47.1 , an oxygen-bearing methane carbon at $\delta 80.9$, a set of olefinic carbon at $\delta 122.9$ and 144.1, an ester carbonyl carbon at $\delta 176.5$, and four anomeric carbons at $\delta 95.7,101.8,105.3$, and 105.3. These spectral data indicated that 3 was the 3,28-bisdesmoside of hederagenin, ${ }^{7)}$ possessing four monosaccharide units. The configuration of the hydroxyl group at C-3 bearing a saccharide moiety was determined to be $\beta$ from the coupling constants of the proton (dd, $J=4.5,11.5 \mathrm{~Hz}, \mathrm{H}-3$ ). Hydrolysis of 
3 afforded hederagenin, D-glucose, L-rhamnose, and D-xylose. The anomeric center of the xylose moiety was determined to be $\beta$-configuration from the ${ }^{3} \mathrm{~J}_{\mathrm{H} 1-\mathrm{H} 2}$ value. The ${ }^{4} \mathrm{C}_{1}$ conformation of xylose was shown by comparison of the ${ }^{13} \mathrm{C}$ shifts for monosaccharide. Meanwhile, the NMR data of $\mathbf{3}$ showed that the glucose and rhamnose moieties had the identical anomeric centers and conformations to $\mathbf{1}$, respectively. In the HMBC experiments, the anomeric proton signals at $\delta$ 5.01 (glc H-1"), 5.04 (xyl H-1), 6.23 (glc H-1'), and 6.49 (rha H-1) showed long-range correlations with the carbon signals at $\delta 69.4$ (glc C-6'), 80.9 (C-3), 176.5 (C-28), and 77.8 (xyl C-2), respectively. Thus, the structure of 3 was elucidated as $3-O-\alpha$-L-rhamnopyranosyl-( $1 \rightarrow 2)-\beta$-D-xylopyranosyl hederagenin 28 - $\beta$-D-glucopyranosyl- $(1 \rightarrow 6)-\beta$-D-glucopyranosyl ester.

The molecular formula of nigelloside D (4) was higher by $\mathrm{C}_{6} \mathrm{H}_{10} \mathrm{O}_{5}$ than that of 3 . A comparative study of the ${ }^{1} \mathrm{H}-\mathrm{NMR}$ spectrum of $\mathbf{4}$ with that of $\mathbf{3}$ revealed them to be identical except for the appearance of the new additional anomeric proton at $\delta 5.50(\mathrm{~d}, J=8.0 \mathrm{~Hz})$. Furthermore, a detailed comparison of the ${ }^{13} \mathrm{C}$-NMR spectrum of $\mathbf{4}$ with that of $\mathbf{3}$ showed the signal due to C-3 of rhamnose, which was shifted remarkably downfield by $10.5 \mathrm{ppm}$, and additional six carbon signals (106.9, 78.7, 78.4, 75.9, 71.5, 62.5). Hydrolysis of 4 afforded hederagenin, D-glucose, L-rhamnose, and D-xylose. The foregoing evidence indicated the presence of an additional glucosyl unit, which was linked to the hydroxyl group at C-3 of the rhamnose moiety, in 4 . The amomeric proton signals at $\delta$ 5.50 (glu H-1"') showed long-range correlations with the carbon signals at $\delta 83.1$ (rha C-3). Consequently, 4 was characterized as 3-O- $\beta$-D-glucopyranosyl-( $1 \rightarrow 3)-\alpha$-L-rhamnopyranosyl-( $1 \rightarrow 2)-\beta$-D-xylopyranosyl hederagenin $28-\beta$-D-glucopyranosyl-( $1 \rightarrow 6)-\beta$-D-glucopyranosyl ester.

In regard to the chemical constituents of $N$. damascena, alkaloid, ${ }^{1)}$ sesquiterpenes, ${ }^{2)}$ and phenolic compounds ${ }^{3)}$ have been characterized from the seeds, but no report on the aerial parts (leaves and stems) has been published to date. To our knowledge, these triterpene glycosides (1-12) are first isolated from $N$. damascena. Meanwhile, a sugar sequence of 3$O$ - $\beta$-D-glucopyranosyl-( $1 \rightarrow 3)-\alpha$-L-rhamnopyranosyl-( $(1 \rightarrow 2)$ $\alpha$-L-arabinopyranosyl or 3-O- $\alpha$-L-rhamnopyranosyl- $(1 \rightarrow 2)$ $\alpha$-L-arabinopyranosyl has been isolated from the Araliaceae, Caprifoliaceae, Dipsacaceae, Ranunculaceae, Umbelliferae and Valerianaceae plants. A sugar sequences of 3-O- $\beta$-Dglucopyranosyl-( $1 \rightarrow 3)$ - $\alpha$-L-rhamnopyranosyl- $(1 \rightarrow 2)-\beta$-Dxylopyranosyl and $3-O-\alpha$-L-rhamnopyranosyl- $(1 \rightarrow 2)-\beta$-Dxylopyranosyl has been isolated from the Anemone anhuiensis (Ranunculaceae) ${ }^{13)}$ and Scabiosa tschiliensis (Dipsacaceae) ${ }^{11)}$ respectively. These saccharide moiety containing D-xylose are rare sugar sequence.

\section{Experimental}

General Procedure Optical rotations were taken with a JASCO DIP1000 automatic digital polarimeter. The NMR spectra were measured with a JEOL ECA 500 NMR spectrometer. The NMR samples of compounds $1-$ 12 were prepared by pyridine- $d_{5}$. Chemical shifts are given on a $\delta(\mathrm{ppm})$ scale with tetramethylsilane (TMS) as an internal standard. The HR-ESI-MS was recorded with a JEOL JMS-T100LP spectrometer. HPLC was carried out using a TSK gel-120A $(7.8 \mathrm{~mm}$ i.d. $\times 30 \mathrm{~cm})$ column with a Tosoh CCPM pump, Tosoh RI-8010 detector, and JASCO OR-2090 detector. TLC was performed on pre-coated Kieselgel $60 \mathrm{~F}_{254}$ plates (Merck), and detection was achieved by spraying with $10 \% \mathrm{H}_{2} \mathrm{SO}_{4}$ followed by heating. Column chromatography was carried out on Kieselgel (230 - 400 mesh, Merck), ODS (PrePAK-500/ $\mathrm{C}_{18}$, Waters) and MCI gel CHP20P (Mitsubishi Chemi- cal Ind.).

Plant Material The plant seeds, defined as the seeds of $N$. damascena, were provided by Sakata Seed Corp., Kanagawa, Japan. The plant seeds were cultivated at the Botanical Garden of Kumamoto University.

Extraction and Isolation The air-dried aerial parts (leaves and stems) of $N$. damascena $(1.0 \mathrm{~kg})$ was extracted with $\mathrm{MeOH}$ at room temperature for one month. The $\mathrm{MeOH}$ extract $(52 \mathrm{~g})$ was partitioned between chloroformsoluble $(9 \mathrm{~g})$ and water-soluble $(43 \mathrm{~g})$ portions. The water-soluble portion was subjected to MCI gel CHP20P column chromatography $\left(\mathrm{MeOH} / \mathrm{H}_{2} \mathrm{O}\right.$, $1: 4 \rightarrow 4: 1)$ to afford five fractions [Fractions $1(3.7 \mathrm{~g}), 2(286 \mathrm{mg}), 3$ $(334 \mathrm{mg}), 4(212 \mathrm{mg})$, and $5(101 \mathrm{mg})]$. Fraction $1(3.7 \mathrm{~g})$ was further separated by ODS column chromatography $\left(\mathrm{MeOH} / \mathrm{H}_{2} \mathrm{O}, 2: 3 \rightarrow 7: 3\right)$ to afford four fractions [Fr. 1-1 (72 mg), Fr. 1-2 (442 mg), Fr. 1-3 (1.9 g), and Fr. 1-4 $(413 \mathrm{mg})$ ]. Fraction 1-3 (1.9 g) was subjected to silica gel column chromatography $\left(\mathrm{CHCl}_{3} / \mathrm{MeOH} / \mathrm{H}_{2} \mathrm{O}, 6: 4: 1\right)$, followed by $\mathrm{HPLC}\left(\mathrm{MeOH} / \mathrm{H}_{2} \mathrm{O}\right.$, 13:7), to furnish compounds 5 (493 mg) and 6 (782 mg). Fraction 1-4 $(413 \mathrm{mg})$ was subjected to silica gel column chromatography $\left(\mathrm{CHCl}_{3} /\right.$ $\left.\mathrm{MeOH} / \mathrm{H}_{2} \mathrm{O}, 6: 4: 1\right)$, followed by $\mathrm{HPLC}\left(\mathrm{MeOH} / \mathrm{H}_{2} \mathrm{O}, 7: 3\right)$, to furnish compounds $3(160 \mathrm{mg})$ and $4(142 \mathrm{mg})$. Fraction $2(286 \mathrm{mg})$ was subjected to silica gel column chromatography $\left(\mathrm{CHCl}_{3} / \mathrm{MeOH} / \mathrm{H}_{2} \mathrm{O}, 6: 4: 1\right)$, followed by HPLC $\left(\mathrm{MeOH} / \mathrm{H}_{2} \mathrm{O}, 7: 3\right)$, to furnish compound $2(98 \mathrm{mg})$. Fraction 3 $(334 \mathrm{mg})$ was further separated by ODS column chromatography $(\mathrm{MeOH} /$ $\left.\mathrm{H}_{2} \mathrm{O}, 1: 1 \rightarrow 7: 3\right)$ to afford three fractions [Fr. 3-1 (66 mg), Fr. 3-2 (22 mg), and Fr. 3-3 (196 mg)]. Fraction 3-1 (66 mg) was subjected to silica gel column chromatography $\left(\mathrm{CHCl}_{3} / \mathrm{MeOH} / \mathrm{H}_{2} \mathrm{O}, 12: 8: 1\right)$, followed by HPLC $\left(\mathrm{MeOH} / \mathrm{H}_{2} \mathrm{O}, 7: 3\right)$, to furnish compound $1(46 \mathrm{mg})$. Fraction 3-2 $(22 \mathrm{mg})$ was subjected to silica gel column chromatography $\left(\mathrm{CHCl}_{3} / \mathrm{MeOH} / \mathrm{H}_{2} \mathrm{O}\right.$, $12: 8: 1)$, followed by $\mathrm{HPLC}\left(\mathrm{MeOH} / \mathrm{H}_{2} \mathrm{O}, 7: 3\right)$, to furnish compound 7 $(6 \mathrm{mg})$. Fraction 3-3 (196 mg) was subjected to silica gel column chromatography $\left(\mathrm{CHCl}_{3} / \mathrm{MeOH} / \mathrm{H}_{2} \mathrm{O}, 12: 8: 1\right)$, followed by $\mathrm{HPLC}\left(\mathrm{MeOH} / \mathrm{H}_{2} \mathrm{O}, 3: 1\right)$, to furnish compound $\mathbf{8}(158 \mathrm{mg})$. Fraction $4(212 \mathrm{mg})$ was further separated by ODS column chromatography $\left(\mathrm{MeOH} / \mathrm{H}_{2} \mathrm{O}, 3: 2 \rightarrow 7: 3\right)$ to afford two fractions [Fr. 4-1 $(74 \mathrm{mg})$ and Fr. 4-2 $(105 \mathrm{mg})$ ]. Fraction 4-1 $(74 \mathrm{mg})$ was subjected to silica gel column chromatography $\left(\mathrm{CHCl}_{3} / \mathrm{MeOH} / \mathrm{H}_{2} \mathrm{O}\right.$, $12: 8: 1)$, followed by HPLC $\left(\mathrm{MeOH} / \mathrm{H}_{2} \mathrm{O}, 3: 1\right)$, to furnish compound 9 $(54 \mathrm{mg})$. Fraction 4-2 (105 $\mathrm{mg})$ was subjected to silica gel column chromatography $\left(\mathrm{CHCl}_{3} / \mathrm{MeOH} / \mathrm{H}_{2} \mathrm{O}, 12: 8: 1\right)$, followed by $\mathrm{HPLC}\left(\mathrm{MeOH} / \mathrm{H}_{2} \mathrm{O}\right.$, $3: 1)$, to furnish compounds $\mathbf{1 0}(42 \mathrm{mg})$ and $\mathbf{1 1}(15 \mathrm{mg})$. Fraction $5(101 \mathrm{mg})$ was subjected to silica gel column chromatography $\left(\mathrm{CHCl}_{3} / \mathrm{MeOH} / \mathrm{H}_{2} \mathrm{O}\right.$, $12: 8: 1)$, followed by $\mathrm{HPLC}\left(\mathrm{MeOH} / \mathrm{H}_{2} \mathrm{O}, 4: 1\right)$, to furnish compound 12 (7 mg).

Nigelloside A (1): A white powder, $[\alpha]_{\mathrm{D}}^{25}-0.67^{\circ}(c=0.98, \mathrm{MeOH})$. HRESI-MS $(\mathrm{m} / \mathrm{z})$ : $1095.5361\left(\mathrm{M}+\mathrm{Na}\right.$; Calcd for $\mathrm{C}_{53} \mathrm{H}_{84} \mathrm{O}_{22} \mathrm{Na}$ : 1095.5352$) .{ }^{1} \mathrm{H}-$ NMR (pyridine- $\left.d_{5}\right) \delta: 0.87(3 \mathrm{H}, \mathrm{s}, \mathrm{H}-29), 0.88(3 \mathrm{H}, \mathrm{s}, \mathrm{H}-30), 0.89(3 \mathrm{H}, \mathrm{s}, \mathrm{H}-$ 25), 1.05 (3H, s, H-26), 1.21 (3H, s, H-27), 1.39 (3H, s, H-24), 1.67 (3H, d, $J=6.3 \mathrm{~Hz}$ rha H-6), $3.17(1 \mathrm{H}$, dd, $J=3.8,13.5 \mathrm{~Hz}, \mathrm{H}-18), 3.71(1 \mathrm{H}, \mathrm{brd}$, $J=9.7 \mathrm{~Hz}$ ara $\mathrm{H}-5 \mathrm{a}), 3.86\left(1 \mathrm{H}, \mathrm{m}, \mathrm{glc} \mathrm{H}-5^{\prime \prime}\right), 3.98(1 \mathrm{H}, \mathrm{dd}, J=7.6,9.1 \mathrm{~Hz}$, glc H-2"), $4.08(1 \mathrm{H}, \mathrm{dd}, J=4.6,11.5 \mathrm{~Hz}, \mathrm{H}-3), 4.08(1 \mathrm{H}$, overlapped, glc $\mathrm{H}-$ $\left.5^{\prime}\right), 4.10\left(1 \mathrm{H}, \mathrm{dd}, J=7.9,9.1 \mathrm{~Hz}\right.$, glc $\left.\mathrm{H}-2^{\prime}\right), 4.16(1 \mathrm{H}, \mathrm{dd}, J=9.1,9.1 \mathrm{~Hz}$, glc H-3"), $4.18\left(1 \mathrm{H}, \mathrm{dd}, J=9.1,9.1 \mathrm{~Hz}\right.$, glc $\left.\mathrm{H}-3^{\prime}\right), 4.18(1 \mathrm{H}$, overlapped, ara $\mathrm{H}-$ 3), $4.19\left(1 \mathrm{H}\right.$, dd, $J=9.1,9.1 \mathrm{~Hz}$, glc $\left.\mathrm{H}-4^{\prime \prime}\right), 4.20(1 \mathrm{H}$, overlapped, ara $\mathrm{H}-4)$, $4.25(1 \mathrm{H}, \mathrm{dd}, J=9.2,9.2 \mathrm{~Hz}$, rha H-4), $4.26(1 \mathrm{H}, \mathrm{dd}, J=4.6,13.5 \mathrm{~Hz}$, ara $\mathrm{H}-$ $5 b), 4.32\left(1 \mathrm{H}, \mathrm{dd}, J=9.1,9.1 \mathrm{~Hz}\right.$, glc $\left.\mathrm{H}-4^{\prime}\right), 4.33$ (each $1 \mathrm{H}$, dd, $J=4.6$, $11.4 \mathrm{~Hz}$, glc H-6'a and glc H-6"a), $4.43(1 \mathrm{H}, \mathrm{dd}, J=5.8,7.5 \mathrm{~Hz}$, ara $\mathrm{H}-2)$, $4.46(1 \mathrm{H}$, dd, $J=1.7,11.4 \mathrm{~Hz}$, glc $\mathrm{H}-6 " \mathrm{~b}), 4.53(1 \mathrm{H}, \mathrm{m}$, rha H-5), $4.57(1 \mathrm{H}$, dd, $J=3.4,9.2 \mathrm{~Hz}$, rha H-3), $4.65(1 \mathrm{H}$, br d, $J=3.4 \mathrm{~Hz}$, rha $\mathrm{H}-2), 4.69(1 \mathrm{H}$, br d, $J=10.3 \mathrm{~Hz}$, glc H-6'b), $4.72(1 \mathrm{H}, \mathrm{d}, J=5.8 \mathrm{~Hz}$, ara H-1), $5.01(1 \mathrm{H}, \mathrm{d}$, $J=7.6 \mathrm{~Hz}$, glc H-1"), $5.39(1 \mathrm{H}$, br s, H-12), $6.06(1 \mathrm{H}$, br s, rha H-1), 6.22 $\left(1 \mathrm{H}, \mathrm{d}, J=7.9 \mathrm{~Hz}\right.$, glc $\left.\mathrm{H}-1^{\prime}\right), 9.67(1 \mathrm{H}, \mathrm{s}, \mathrm{H}-23) .{ }^{13} \mathrm{C}-\mathrm{NMR}$ (pyridine- $\left.d_{5}\right) \delta$ : given in Table 1.

Nigelloside B (2): A white powder, $[\alpha]_{\mathrm{D}}^{25}-1.74^{\circ}(c=0.35, \mathrm{MeOH})$. HRESI-MS $(m / z)$ : $1257.5864\left(\mathrm{M}+\mathrm{Na}\right.$; Calcd for $\left.\mathrm{C}_{59} \mathrm{H}_{94} \mathrm{O}_{27} \mathrm{Na}: 1257.5880\right) .{ }^{1} \mathrm{H}-$ NMR (pyridine- $\left.d_{5}\right) \delta: 0.87(3 \mathrm{H}, \mathrm{s}, \mathrm{H}-29), 0.88(3 \mathrm{H}, \mathrm{s}, \mathrm{H}-30), 0.89(3 \mathrm{H}, \mathrm{s}, \mathrm{H}-$ 25), 1.05 (3H, s, H-26), 1.22 (3H, s, H-27), $1.47(3 \mathrm{H}, \mathrm{s}, \mathrm{H}-24), 1.60(3 \mathrm{H}, \mathrm{d}$, $J=6.3 \mathrm{~Hz}$ rha H-6), $3.18(1 \mathrm{H}$, dd, $J=4.0,13.7 \mathrm{~Hz}, \mathrm{H}-18), 3.70(1 \mathrm{H}, \mathrm{brd}$, $J=10.4 \mathrm{~Hz}$ ara $\mathrm{H}-5 \mathrm{a}), 3.87\left(1 \mathrm{H}, \mathrm{m}, \mathrm{glc} \mathrm{H}-5^{\prime \prime}\right), 3.99(1 \mathrm{H}, \mathrm{dd}, J=8.0,9.1 \mathrm{~Hz}$, glc $\left.\mathrm{H}-2^{\prime \prime}\right), 4.03\left(1 \mathrm{H}, \mathrm{m}\right.$, glc $\left.\mathrm{H}-5^{\prime \prime \prime}\right), 4.09(1 \mathrm{H}$, overlapped, ara $\mathrm{H}-3), 4.10(1 \mathrm{H}$, overlapped, glc $\left.\mathrm{H}-5^{\prime}\right), 4.11$ (each $1 \mathrm{H}$, dd, $J=8.1,9.1 \mathrm{~Hz}$, glc $\mathrm{H}-2^{\prime}$ and glc $\mathrm{H}-$ $\left.2^{\prime \prime \prime}\right), 4.16(1 \mathrm{H}$, br s, ara H-4), 4.19 (each $1 \mathrm{H}, \mathrm{dd}, J=9.1,9.1 \mathrm{~Hz}$, glc H-3" and glc $\left.\mathrm{H}-4^{\prime \prime}\right), 4.21\left(1 \mathrm{H}, \mathrm{dd}, J=9.1,9.1 \mathrm{~Hz}\right.$, glc $\left.\mathrm{H}-3^{\prime}\right), 4.25(1 \mathrm{H}, \mathrm{dd}, J=3.4$, $12.1 \mathrm{~Hz}$, ara $\mathrm{H}-5 \mathrm{~b}$ ), $4.27\left(1 \mathrm{H}\right.$, dd, $J=9.1,9.1 \mathrm{~Hz}$, glc $\mathrm{H}-3^{\prime \prime \prime}$ ), 4.31 (each $1 \mathrm{H}$, dd, $J=9.1,9.1 \mathrm{~Hz}$, glc $\mathrm{H}-4^{\prime}$ and glc $\mathrm{H}-4^{\prime \prime \prime}$ ), 4.35 (each $1 \mathrm{H}$, dd, $J=4.9$, $11.4 \mathrm{~Hz}$, glc H-6'a and glc H-6"a), 4.39 (1H, dd, $J=4.9,11.3 \mathrm{~Hz}$, glc H-6"' a), $4.44(1 \mathrm{H}, \mathrm{dd}, J=6.3,8.5 \mathrm{~Hz}$, ara $\mathrm{H}-2), 4.47(1 \mathrm{H}$, br d, $J=11.4 \mathrm{~Hz}$, glc $\mathrm{H}-$ 
$\left.6^{\prime \prime} \mathrm{b}\right), 4.48\left(1 \mathrm{H}, \mathrm{dd}, J=1.8,11.3 \mathrm{~Hz}, \mathrm{glc} \mathrm{H}-6^{\prime \prime \prime} \mathrm{b}\right), 4.48(1 \mathrm{H}, \mathrm{dd}, J=9.1,9.1 \mathrm{~Hz}$, rha $\mathrm{H}-4), 4.58(1 \mathrm{H}, \mathrm{m}$, rha $\mathrm{H}-5), 4.65(1 \mathrm{H}, \mathrm{d}, J=6.3 \mathrm{~Hz}$, ara $\mathrm{H}-1), 4.71(1 \mathrm{H}$ br d, $J=9.8 \mathrm{~Hz}$, glc $\mathrm{H}-6^{\prime}$ b) $, 4.81(1 \mathrm{H}, \mathrm{dd}, J=2.9,9.1 \mathrm{~Hz}$, rha $\mathrm{H}-3), 4.95(1 \mathrm{H}$, br d, $J=2.9 \mathrm{~Hz}$, rha H-2), $5.03\left(1 \mathrm{H}, \mathrm{d}, J=8.0 \mathrm{~Hz}, \mathrm{glc} \mathrm{H}-1^{\prime \prime}\right), 5.39(1 \mathrm{H}, \mathrm{br} \mathrm{s}, \mathrm{H}-$ 12), $5.64\left(1 \mathrm{H}, \mathrm{d}, J=8.1 \mathrm{~Hz}\right.$, glc $\left.\mathrm{H}-1^{\prime \prime \prime}\right), 6.17(1 \mathrm{H}, \mathrm{d}, J=1.2 \mathrm{~Hz}$, rha $\mathrm{H}-1), 6.24$ $\left(1 \mathrm{H}, \mathrm{d}, J=8.0 \mathrm{~Hz}\right.$, glc $\left.\mathrm{H}-1^{\prime}\right), 9.78(1 \mathrm{H}, \mathrm{s}, \mathrm{H}-23) .{ }^{13} \mathrm{C}-\mathrm{NMR}$ (pyridine- $\left.d_{5}\right) \delta$ : given in Table 1.

Nigelloside C (3): A white powder, $[\alpha]_{\mathrm{D}}^{25}-10.5^{\circ}(c=0.93, \mathrm{MeOH})$. HRESI-MS (m/z): $1097.5492\left(\mathrm{M}+\mathrm{Na}\right.$; Calcd for $\left.\mathrm{C}_{53} \mathrm{H}_{86} \mathrm{O}_{22} \mathrm{Na}: 1097.5508\right) .{ }^{1} \mathrm{H}-$ NMR (pyridine- $\left.d_{5}\right) \delta: 0.84(3 \mathrm{H}, \mathrm{s}, \mathrm{H}-29), 0.85(3 \mathrm{H}, \mathrm{s}, \mathrm{H}-30), 0.97(3 \mathrm{H}, \mathrm{s}, \mathrm{H}-$ 25), $1.11(3 \mathrm{H}, \mathrm{s}, \mathrm{H}-26), 1.12(3 \mathrm{H}, \mathrm{s}, \mathrm{H}-27), 1.17(3 \mathrm{H}, \mathrm{s}, \mathrm{H}-27), 1.67(3 \mathrm{H}, \mathrm{d}$, $J=6.3 \mathrm{~Hz}$ rha H-6), $3.16(1 \mathrm{H}$, dd, $J=4.0,13.7 \mathrm{~Hz}, \mathrm{H}-18), 3.54(1 \mathrm{H}, \mathrm{t}$, $J=10.9 \mathrm{~Hz}$, xyl H-5a), $3.72(1 \mathrm{H}, \mathrm{d}, J=9.8 \mathrm{~Hz}, \mathrm{H}-23 \mathrm{a}), 3.98$ (each $1 \mathrm{H}, \mathrm{dd}$, $J=9.1,9.1 \mathrm{~Hz}$, xyl H-3 and glc H-2"), $3.86(1 \mathrm{H}, \mathrm{m}$, glc H-5"), 4.09 (each $1 \mathrm{H}$, overlapped, xyl H-4 and glc $\left.\mathrm{H}-5^{\prime}\right), 4.10\left(1 \mathrm{H}\right.$, dd, $J=8.1,9.1 \mathrm{~Hz}$, glc $\left.\mathrm{H}-2^{\prime}\right)$, $4.16(1 \mathrm{H}, \mathrm{dd}, J=9.1,9.1 \mathrm{~Hz}$, glc H-3") $4.17(1 \mathrm{H}, \mathrm{dd}, J=9.1,9.1 \mathrm{~Hz}$, glc H$\left.3^{\prime}\right), 4.19(1 \mathrm{H}, \mathrm{dd}, J=9.1,9.1 \mathrm{~Hz}$, glc H-4"), $4.20(1 \mathrm{H}, \mathrm{dd}, J=7.5,9.1 \mathrm{~Hz}$, xyl $\mathrm{H}-2), 4.23(1 \mathrm{H}$, overlapped, H-23b), $4.25(1 \mathrm{H}, \mathrm{dd}, J=5.2,10.9 \mathrm{~Hz}, \mathrm{xyl} \mathrm{H}-$ $5 \mathrm{~b}), 4.27(1 \mathrm{H}, \mathrm{dd}, J=4.5,11.5 \mathrm{~Hz}, \mathrm{H}-3), 4.30(1 \mathrm{H}, \mathrm{dd}, J=9.2,9.2 \mathrm{~Hz}$, rha H4), $4.32\left(1 \mathrm{H}, \mathrm{dd}, J=9.1,9.1 \mathrm{~Hz}\right.$, glc $\left.\mathrm{H}-4^{\prime}\right), 4.33$ (each $1 \mathrm{H}$, dd, $J=4.6$, $11.5 \mathrm{~Hz}$ glc $\mathrm{H}-6^{\prime} \mathrm{a}$ and glc $\left.\mathrm{H}-6{ }^{\prime \prime} \mathrm{a}\right), 4.45\left(1 \mathrm{H}\right.$, brd, $J=10.3 \mathrm{~Hz}$, glc $\left.\mathrm{H}-6^{\prime \prime} \mathrm{b}\right)$, $4.66(1 \mathrm{H}, \mathrm{dd}, J=3.5,9.2 \mathrm{~Hz}$, rha H-3), $4.68(1 \mathrm{H}, \mathrm{dd}, J=1.7,11.5 \mathrm{~Hz}$, glc $\mathrm{H}-$ $\left.6^{\prime} \mathrm{b}\right), 4.76(1 \mathrm{H}, \mathrm{m}$, rha H-5), $4.79(1 \mathrm{H}, \mathrm{brd}, J=3.5 \mathrm{~Hz}$, rha H-2), $5.01(1 \mathrm{H}, \mathrm{d}$, $J=8.0 \mathrm{~Hz}$, glc H-1"), $5.04(1 \mathrm{H}, \mathrm{d}, J=7.5 \mathrm{~Hz}$, xyl H-1), $5.39(1 \mathrm{H}, \mathrm{dd}, J=2.9$, $3.5 \mathrm{~Hz}, \mathrm{H}-12), 6.23\left(1 \mathrm{H}, \mathrm{d}, J=8.1 \mathrm{~Hz}\right.$, glc $\left.\mathrm{H}-1^{\prime}\right), 6.49(1 \mathrm{H}, \mathrm{d}, J=1.2 \mathrm{~Hz}$, rha $\mathrm{H}-1) .{ }^{13} \mathrm{C}-\mathrm{NMR}$ (pyridine- $d_{5}$ ) $\delta$ : given in Table 1

Nigelloside D (4): A white powder, $[\alpha]_{\mathrm{D}}^{25}-14.0^{\circ}(c=0.96, \mathrm{MeOH})$. HRFAB-MS $(\mathrm{m} / \mathrm{z})$ : $1259.6053\left(\mathrm{M}+\mathrm{Na}\right.$; Calcd for $\mathrm{C}_{59} \mathrm{H}_{96} \mathrm{O}_{27} \mathrm{Na}$ : 1259.6037). ${ }^{1} \mathrm{H}-\mathrm{NMR}$ (pyridine- $\left.d_{5}\right) \delta: 0.85(3 \mathrm{H}, \mathrm{s}, \mathrm{H}-30), 0.86(3 \mathrm{H}, \mathrm{s}, \mathrm{H}-29), 0.97(3 \mathrm{H}$, s, H-25), 1.11 (3H, s, H-26), 1.18 (3H, s, H-24), 1.18 (3H, s, H-27), 1.62 $(3 \mathrm{H}, \mathrm{d}, J=6.3 \mathrm{~Hz}$ rha $\mathrm{H}-6), 3.17(1 \mathrm{H}, \mathrm{dd}, J=4.1,13.8 \mathrm{~Hz}, \mathrm{H}-18), 3.53(1 \mathrm{H}$, dd, $J=10.6,10.9 \mathrm{~Hz}$, xyl H-5a), $3.86\left(1 \mathrm{H}, \mathrm{m}, \mathrm{glc} \mathrm{H}-5^{\prime \prime}\right), 3.93(1 \mathrm{H}, \mathrm{d}$, $J=10.3 \mathrm{~Hz}, \mathrm{H}-23 \mathrm{a}), 3.96\left(1 \mathrm{H}, \mathrm{m}\right.$. glc $\left.\mathrm{H}-5^{\prime \prime \prime}\right), 3.99(1 \mathrm{H}, \mathrm{dd}, J=7.5,9.1 \mathrm{~Hz}$, glc H-2"), $4.09(1 \mathrm{H}$, dd, $J=8.0,9.1 \mathrm{~Hz}$, glc H-2"'), $4.10(1 \mathrm{H}, \mathrm{dd}, J=8.0,9.1 \mathrm{~Hz}$ glc $\mathrm{H}-2^{\prime}$ ), 4.11 (each $1 \mathrm{H}$, overlapped, xyl H-3, xyl H-4, and glc $\mathrm{H}-5^{\prime}$ ), 4.17 $(1 \mathrm{H}, \mathrm{dd}, J=8.0,9.1 \mathrm{~Hz}, \mathrm{xyl} \mathrm{H}-2), 4.18$ (each $1 \mathrm{H}, \mathrm{dd}, J=9.1,9.1 \mathrm{~Hz}$, glc H-3" and glc $\left.\mathrm{H}-4^{\prime \prime}\right), 4.20\left(1 \mathrm{H}\right.$, dd, $J=9.1,9.1 \mathrm{~Hz}$, glc $\left.\mathrm{H}-3^{\prime}\right), 4.24$ (each $1 \mathrm{H}$, overlapped, xyl H-5b, glc H-3"' and glc H-4"'), $4.26(1 \mathrm{H}, \mathrm{dd}, J=4.6,10.3 \mathrm{~Hz}$, glc H-6"'a), 4.30 (1H, dd, $J=4.6,11.5 \mathrm{~Hz}, \mathrm{H}-3), 4.31(1 \mathrm{H}, \mathrm{dd}, J=9.1,9.1 \mathrm{~Hz}, \mathrm{glc}$ H-4'), 4.35 (each $1 \mathrm{H}, \mathrm{dd}, J=5.2,11.5 \mathrm{~Hz}$, glc H-6'a and glc H-6"a), 4.39 $(1 \mathrm{H}, \mathrm{d}, J=10.3 \mathrm{~Hz}, \mathrm{H}-23 \mathrm{~b}$ ), 4.45 (each $1 \mathrm{H}, \mathrm{brd}, J=12.1 \mathrm{~Hz}$, glc H-6"b and glc $\left.\mathrm{H}-6^{\prime \prime \prime} \mathrm{b}\right), 4.51(1 \mathrm{H}$, dd, $J=9.1,9.1 \mathrm{~Hz}$, rha H-4), $4.70(1 \mathrm{H}, \mathrm{brd}, J=9.8 \mathrm{~Hz}$, glc $\left.\mathrm{H}-6{ }^{\prime} \mathrm{b}\right), 4.76(1 \mathrm{H}, \mathrm{m}$, rha $\mathrm{H}-5), 4.89(1 \mathrm{H}, \mathrm{dd}, J=2.9,9.1 \mathrm{~Hz}$, rha $\mathrm{H}-3)$, $5.00\left(1 \mathrm{H}\right.$, br d, $J=2.9 \mathrm{~Hz}$, rha H-2), $5.01\left(1 \mathrm{H}, \mathrm{d}, J=7.5 \mathrm{~Hz}\right.$, glc $\left.\mathrm{H}-1^{\prime \prime}\right), 5.03$ $(1 \mathrm{H}, \mathrm{d}, J=8.0 \mathrm{~Hz}, \mathrm{xyl} \mathrm{H}-1), 5.39(1 \mathrm{H}, \mathrm{dd}, J=3.4,3.5 \mathrm{~Hz}, \mathrm{H}-12), 5.50(1 \mathrm{H}, \mathrm{d}$, $J=8.0 \mathrm{~Hz}$, glc H-1"')$) 6.24\left(1 \mathrm{H}, \mathrm{d}, J=8.0 \mathrm{~Hz}\right.$, glc $\left.\mathrm{H}-1^{\prime}\right), 6.49(1 \mathrm{H}, \mathrm{d}$,
$J=1.2 \mathrm{~Hz}$, rha H-1). ${ }^{13} \mathrm{C}-\mathrm{NMR}$ (pyridine- $d_{5}$ ) $\delta$ : given in Table 1.

Sugar Analysis A solution of each compound $(1,2,3$, or 4) $(2 \mathrm{mg})$ in $2 \mathrm{~N} \mathrm{HCl} /$ dioxane $(1: 1,2 \mathrm{ml})$ was heated at $100^{\circ} \mathrm{C}$ for $1 \mathrm{~h}$. The reaction mixture was diluted with $\mathrm{H}_{2} \mathrm{O}$ and evaporated to remove dioxane. The solution was neutralized with Amberlite MB-3 and passed through a SEP-PAK $\mathrm{C}_{18}$ cartridge to give a sugar fraction. The sugar fraction was concentrated to dryness in vacuo to give a residue, which was dissolved in $\mathrm{CH}_{3} \mathrm{CN} / \mathrm{H}_{2} \mathrm{O}$ $(3: 1,250 \mu 1)$. The sugar fraction was analyzed by HPLC under the following conditions: column, Shodex RS-Pac DC-613 $(6.0 \mathrm{~mm}$ i.d. $\times 150 \mathrm{~mm}$, Showa Denko, Tokyo, Japan); solvent, $\mathrm{CH}_{3} \mathrm{CN} / \mathrm{H}_{2} \mathrm{O}$ (3:1); flow rate, $1.0 \mathrm{ml} / \mathrm{min}$; column temperature, $70^{\circ} \mathrm{C}$; detection, optical rotation (OR). The $t_{\mathrm{R}}(\mathrm{min})$ of the sugars was detected as follows. 1: L-rhamnose $4.7(-)$, L-arabinose $6.3(+)$, D-glucose $7.4(+)$, 2: L-rhamnose $4.7(-)$, L-arabinose 6.3 $(+)$, D-glucose $7.4(+)$, 3: L-rhamnose $4.7(-)$, D-xylose $5.5(+)$, D-glucose $7.4(+), 4$ : L-rhamnose $4.7(-)$, D-xylose $5.5(+)$, D-glucose $7.4(+)$. [Reference: L-rhamnose 4.7 (negative optical rotation: - ), D-xylose 5.5 (positive optical rotation: + ), L-arabinose 6.3 (positive optical rotation: + ), D-glucose 7.4 (positive optical rotation: + )]

\section{References}

1) Doepke W., Fritsch G., Pharmazie, 25, 69-70 (1970).

2) Tillequin F., Leconte C., Paris M., Planta Med., 30, 59-61 (1976).

3) Agradi E., Fico G., Cillo F., Francisci C., Tome F., Planta Med., 67, $553-555$ (2001)

4) Yoshimitsu H., Nishida M., Yahara S., Nohara T., Tetrahedron Lett., 39, 6919-6920 (1998)

5) Yoshimitsu H., Nishida M., Hashimoto F., Nohara T., Phytochemistry, 51, 449-452 (1999).

6) Nishida M., Yoshimitsu H., Okawa M., Ikeda T., Nohara T., Chem. Pharm. Bull., 51, 1215-1216 (2003).

7) Penders A., Delaude C., Carbohydr. Res., 263, 79-88 (1994).

8) Kizu H., Hirabayashi S., Suzuki M., Tomimori T., Chem. Pharm. Bull., 33, 3473-3478 (1985)

9) Braca A., Autore G., De S. F., Marzocco S., Morelli I., Venturella F., De T. N., Planta Med., 70, 960-966 (2004).

10) Choi J. S., Woo W. S., Planta Med., 53, 62-65 (1987).

11) Zheng Q., Koike K., Han L. K., Okuda H., Nikaido T., J. Nat. Prod., 67, 604-613 (2004).

12) Kawai H., Kuroyanagi M., Umehara K., Ueno A., Satake M., Chem. Pharm. Bull., 36, 4769—4775 (1988).

13) Ye W. C., Zhang Q. W., Zhao S. X., Che C. T., Chem. Pharm. Bull., 49, 632-634 (2001).

14) Saito S., Sumita S., Tamura N., Nagamura Y., Nishida K., Ito M., Ishiguro I., Chem. Pharm. Bull., 38, $411-414$ (1990).

15) Fu H. Z., Koike K., Li W., Nikaido T., Lin W. H., Guo D. A., J. Nat. Prod., 68, 754-758 (2005). 